\title{
THE STUDENTS' SPEAKING ANXIETY: PSYCHO-SOCIAL APPROACH
}

\author{
Syahriana Pratiwi', Muhammad Zuhri Dj. ${ }^{* 2}$, Hasriati Nur ${ }^{3}$ \\ 1,2,3 Department of English Education, Institut Agama Islam Negeri Bone, Indonesia \\ Corresponding Author Email: zuhristaindije@gmail.com
}

\begin{abstract}
This thesis presents research about "Analyzing the Students Speaking Anxiety by Using Psycho-social Approach" The sample consists of 10 students of Al-hasib class at the second grade SMA Islam Athirah Bone. The objective of this research are (1) to analyze the reduction of the students' speaking anxiety by using psycho-social approach. (2) to know the factors that cause students of SMA Islam Athirah Bone to get anxiety in Speaking. This research uses qualitative method by analyzing data using test, observation and interview. The result of the research shows that the students of the eleventh grade of Al-hasib class of SMA Islam Athirah Bone reduces anxiety in speaking by using psycho-social approach. It supported by the existence of social interaction that are often carried out able to make students more confident and no longer anxious, Controlling the students' emotional in studying situation, Relaxation and motivation. They get more guidance from their English teachers such as being relax, preparing the preparation before studying or perform and positive thinking. The most dominant points are relaxation and motivation. The students have some factors in anxiety, they are lack of preparation, learners' belief about language learning, fear of making mistakes and personal and interpersonal factors. The most dominant factors are lack of preparation and fear of making mistake.
\end{abstract}

Keywords: Speaking, Anxiety, Psycho-socialApproach

\section{INTRODUCTION}

The difficulties of speaking as support factors in impeding the students to speak such as they are afraid of making errors in class they have no idea what to say, they are not confident and comfortable if they make mistakes, and they are not interested in with topics that are given by the teacher. (Heriansyah, 2012) There are many pieces research on the relationship between foreign language learning and effective variables and they focuses on a number of personality factors which may have positive or negative effects in foreign language learning process such as extroversion, self-esteem, motivation, and anxiety (Ozturk \& Gurbuz, Speaking Anxiety Among Turkish EFL Learners: The case at a state university, 2014) In this research, the researcher focuses on anxiety of students in speaking.

Anxiety is the subjective feeling of tension, apprehen-sion, nervousness, and worry associated with an arousal of the autonomic nervous system (Elaine, Michael, Horwitz, \& Cope, 2012). In speaking situations, foreign language learners are often anxious about their ability in a foreign language (MacIntyre, 1991) Horwitz mentioned talkative individuals even become silent in a foreign language class as they have speaking anxiety. Hence, they put forward that it plays a crucial role in foreign language learning (Ozturk \& Gurbuz, Speaking Anxiety Among Turkish EFL Learners: The case at a state university, 2014).

In the educational system of Indonesia, it cannot be ignored if students do not enjoy the learning process because of students' speaking anxiety. For this reason, it becomes the main point of this research. The school which is involved with it is SMA Islam Athirah Bone. The researcher is a casual one of the teachers in its English course. By doing pre-observation such as paying attention to the students when they speak English, not all students can enjoy and comfortable with 
IJRETAL

International Journal of Research on English Teaching and Applied Linguistics, Vol. 1, No.1, June 2020

the English subject, some of them still lack confidence, afraid of making mistakes even they fell anxious and shy. It becomes the problem of the students in SMA Islam Athirah Bone. It is influenced by English subjects like Foreign Language Anxiety (FLA). On the other hand, Psychology plays an important role in learning environments as well as the foreign language learning process (Karatasa, Alci, Bademciouglu, \& Ergin, 2014). And the speaking anxiety makes the psychological of students are disturbed during the learning process.

Therefore, it should be known how to solve it. By using an approach that can be more effective to help the students in dealing with their anxiety in the learning process. The researcher used psycho-social as an approach to do interaction in social life well. It helps students understand their own and other people's emotion and behavior and enhance their self- confidence. According to Muzafer Sherif, Psycho- social is a scientific study of the experience and behavior or individuals in relation to social stimulus situations (Sherif, 2017) It helps students understand their own and other people's emotion and behavior and enhance their self-confidence. The experience and behavior will influence the future life of people, and social stimulus situations consist of other people, individuals, or groups.

A lot of researchers who have done psycho-social as their research, but most of them use different both benefit and way, both location and respondent, even the different research of design to be conducted. As research by Diana Harcourt (Harcourt, 2018). She used psycho-social as the provision of specialist support for people with visible differences. She surveyed a Europian. The survey created by members of the Clinical Interventions workgroup of the Appearance Matters COST Action, and we can consider that her research succeeds. Thus, this reason encourages the researcher rising the title "Analyzing the students speaking anxiety by using the psycho-social approach" to be conducted.

The researcher formulates the literary review are:

Speaking involves putting a message together, communicating the message, and interacting with other people (Lindsay, 2006). Speaking a language is difficult for foreign language learners because the ability of effective oral communication requires to use the language appropriately in social interaction (Jack \& Richards, 2002). There are some problems that are often encountered when speaking activites. According to Penny Ur about problem with speaking activities, those are Inhibition, Nothing to say, Low or uneven participation and Mother-tongue use (Ur, 1996).

Anxiety in language learning as an emotional state of apprehension, a vague fear that is only inderectly associated with an object" (Zhang, 2001). Anxiety is concern and fear, especially about what might happen (Bul, 2008). However, Horwitz, and Cope indicate that foreign language anxiety is "a distinct complex of self-perceptions, beliefs, feelings, and behaviors related to classroom language learning arising from the uniqueness of the language learning process" (Hismanoglu, 2012) Anxiety as an affective state is defined as an uncomfortable emotional state in which one perceives danger, feels powerless, and experiences tension in the face an expected danger (Blau, 1955). Foreign language anxiety has three varieties. mature communication skills although they have mature ideas and thoughts (Aydin, 2008).

Communication apprehension occurs in cases where learners lac

The language learners in the present study as follows: Lack of preparation in speaking English and lack of confidence in their ability to learn English and Fear of making mistake and subsequent punishment or ostracism, fear of losing face for not being perfect (Tseng, 2012).

Psychosocial is a branch of psychology. It is the greatest innovation from a development of psychologist and psychoanalyst who is well known for this theory on social development of human beings, and for coining the phrase identity crisis named Erik Erikson from Frankfur. (Anwar, Maggie, \& Crane's, 2014). Psycho-social is a study of the relationship between individuals and groups (G., Myers., \& Hill., 1995). Psycho-social is a study that investigates how thoughts, feelings and behavior of individuals are influenced by the presence of others both actual and imaginative (1A, Hogg, \& Vaughan., 2015). 
IJRETAL

International Journal of Research on English Teaching and Applied Linguistics, Vol. 1, No.1, June 2020

Based on the literature review above, the objectives of the research are: To analyze the reduction of the students' speaking anxiety by using a psycho-social approach at the eleventhgrade students of SMA Islam Athirah Bone and the factors that cause students of SMA Islam Athirah Bone to get anxiety in Speaking.

\section{RESEARCH METHOD}

This research used descriptive qualitative research. This research took place in Athirah Bone and te subject of the research was at the eleventh grade students of XI.MIA Al-Hasib class. In this research, the researcher took subject from SMA Islam were 1 English teacher and 10 students. To analyze the students' speaking anxiety by using a psycho-social approach, the researcher utilized four instruments which consisted of the test, observation, interview, and documentation in collecting data. The test was given to the students like a speaking test to know the students' anxiety. A checklist of observations was arranged by the researcher and the question list of Interviews was arranged by the researcher to ease the implementation of the interview season. This research used descriptive qualitative research.

In conducting research, some steps were required to be done in clear chronological order. In this study, there were several steps to collect the data: Test to know the students' Speaking anxiety, observation to know the implementation of the psycho-social approach in the learning process, open guided interview to avoid the ambiguous explanation to support the activities of observation.

The qualitative data analysis suites this research is from punch. He describes that there are three major components of qualitative data analysis are data reduction, data display and data verification (Punch, 2009). The explanation of the main components is explained as follows:

Data reduction means the process of selecting, focusing, simplifying, abstracting, identifying, and transforming the data appear in written-up field notes and transcriptions. In conducting research, the researcher got much data.

Data display, in displaying data, the researcher describes data that has been reduced into sentence form. In qualitative research, the most frequent form of display data is a narrative text, but the researcher also displays some of the data in the table. The reasons for reducing and displaying data are to assist in drawing conclusions.

Data Verification, While Verifying conclusions logically follows the reduction and display of data. In fact, it takes place more or less concurrently with them. The researcher took the data about the factor cause of students' anxiety in speaking English, and how the psychosocial approach used to overcome the anxiety in speaking English.

\section{FINDINGS AND DISCUSSION}

Based on the instrument of the research that the findings of the students' problem were found by using a Speaking test, Checklist of observation, and open guided question. The test, observation, and interview by the teacher described the reduction of students' anxiety in speaking by using a psycho-social approach, and the interview was used to know the factors that cause students got anxiety. 
IJRETAL

International Journal of Research on English Teaching and Applied Linguistics, Vol. 1, No.1, June 2020

\section{A. FINDINGS}

\section{Reducing Students' Anxiety in Speaking by Using Psycho-social Approach}

Table 1. The Findings of How Psycho-Social Approach Reduced Student's Speakig Anxiety

\begin{tabular}{|c|c|c|c|c|}
\hline No. & Findings & $\begin{array}{l}\text { Transcript of students' } \\
\text { speaking Test } \\
\text { (Telling about feeling and } \\
\text { activities during this } \\
\text { pandemic) }\end{array}$ & $\begin{array}{l}\text { Result of } \\
\text { Observation }\end{array}$ & $\begin{array}{l}\text { Interview by the } \\
\text { English Teacher }\end{array}$ \\
\hline 1. & Social Interaction & $\begin{array}{l}\text { SA } \\
\text { Eee... during this } \\
\text { pandemic, eee.. i.... i feel } \\
\text { happy because... because... } \\
\text { I can... aduh miss i don't } \\
\text { know miss. Mm... I can } \\
\text { together with my eee.. my } \\
\text { family and I am happy. } \\
\text { Begituji miss. } \\
\text { Expressions: } \\
\text { Being confused to say } \\
\text { anything, look at another } \\
\text { object, take long time to } \\
\text { speak. }\end{array}$ & $\begin{array}{l}\text { Based on the } \\
\text { observation,, the } \\
\text { researcher can regard } \\
\text {, by using psycho- } \\
\text { social approach like } \\
\text { doing "Social } \\
\text { Interaction" reduced } \\
\text { the students' anxiety } \\
\text { in speaking. }\end{array}$ & \multirow{3}{*}{$\begin{array}{l}\text { Researcher: } \\
\text { If you find your } \\
\text { students get } \\
\text { anxiety and shy to } \\
\text { speak English How } \\
\text { is your way to } \\
\text { solve those } \\
\text { problems? } \\
\text { Teacher: } \\
\text { I apply the talking } \\
\text { each other such as } \\
\text { conversation even in } \\
\text { a one group. } \\
\text { If I find my students } \\
\text { who are feeling shy, } \\
\text { anxious or nervous. } \\
\text { ask them even face } \\
\text { to face about what } \\
\text { is their problem and } \\
\text { diffilculties. And I } \\
\text { give the the solution } \\
\text { such as motivation, } \\
\text { make them relax, } \\
\text { change their mind to } \\
\text { be positive thinking } \\
\text { and many else. }\end{array}$} \\
\hline 2. & $\begin{array}{l}\text { Controlling The } \\
\text { Students' } \\
\text { Emotional }\end{array}$ & $\begin{array}{l}\text { PA } \\
\quad \text { Okay, my feeling is } \\
\text { khmmm happy because I } \\
\text { can spend my eee... time } \\
\text { with my family mm.. heheh } \\
\text { so many ... so many yeah... } \\
\text { so many benefits lah miss } \\
\text { for myself. Sorry miss } i \\
\text { don't know speaking. } \\
\text { Expressions: Being } \\
\text { confused to say anything, } \\
\text { shy, taking long time to } \\
\text { speak and repeating words } \\
\text { many times. }\end{array}$ & $\begin{array}{l}\text { Based on the } \\
\text { observation,, the } \\
\text { researcher can regard } \\
\text { by using psycho- } \\
\text { social approach like } \\
\text { doing "Controlling } \\
\text { The Students' } \\
\text { Emotional" reduced } \\
\text { the student's anxiety } \\
\text { in speaking. }\end{array}$ & \\
\hline 3. & Relaxation & $\begin{array}{l}\text { AS } \\
\text { Okay.. eee.. my feeling } \\
\text { about this pandemic is eee.. } \\
\text { first.. eee.. how to say } \\
\text { tentunya eee.. i'm so sad } \\
\text { because eee many eee.. like } \\
\text { we are eee.. hearing eee.. }\end{array}$ & $\begin{array}{l}\text { Based on the } \\
\text { observation,, the } \\
\text { researcher can regard } \\
\text {, by using psycho- } \\
\text { social approach like } \\
\text { doing "Relaxation" }\end{array}$ & \\
\hline
\end{tabular}

The Students' Speaking Anxiety: Psycho-Social Approach

Syahriana Pratiwi, Muhammad Zuhri Dj., \& Hasriati Nur, Page 16-27 
IJRETAL

International Journal of Research on English Teaching and Applied Linguistics, Vol. 1, No.1, June 2020

\begin{tabular}{|c|c|c|c|c|}
\hline & & $\begin{array}{l}\text { many people eee... how to } \\
\text { say terkena covid-19. } \\
\text { Expressions: Being shy, } \\
\text { nerveous, taking long time } \\
\text { to speak and saying eee... } \\
\text { many times }\end{array}$ & $\begin{array}{l}\text { reduced the student's } \\
\text { anxiety in speaking. }\end{array}$ & \\
\hline 4. & Motivation & $\begin{array}{l}\text { AM } \\
\text { Thanks for the time, } \\
\text { so during this pandemic, I } \\
\text { try mmm... learn from home } \\
\text { eee.. because this covid-19. } \\
\text { Hmmm... I hope it can close. } \\
\text { But my feeling sometimes } \\
\text { sad and happy. I'm sad } \\
\text { because i can't meet eee.. } \\
\text { with my friends in school. I } \\
\text { happy because heheh i can } \\
\text { always together with.. ee } \\
\text { with.. my family. } \\
\text { Expressions:Being nervous, } \\
\text { thinking too much to say } \\
\text { something and stop in each } \\
\text { middles of speaking. }\end{array}$ & $\begin{array}{l}\text { Based on the } \\
\text { observation,, the } \\
\text { researcher can regard } \\
\text {, by using psycho- } \\
\text { social approach like } \\
\text { giving "Motivation" } \\
\text { reduced the student's } \\
\text { anxiety in speaking. }\end{array}$ & \\
\hline
\end{tabular}

Table 2. Checklist of observation by the student (RSA)

\begin{tabular}{|c|c|c|c|c|}
\hline No & Statement & Yes & No & Description \\
\hline 1. & $\begin{array}{l}\text { Student was able to speak about the } \\
\text { topic that had been prepared consist } \\
\text { of telling himself and his feeling } \\
\text { during this pandemic. }\end{array}$ & $\sqrt{ }$ & & $\begin{array}{l}\text { The student is able to speak } \\
\text { about the topic that has been } \\
\text { prepared by the researcher. }\end{array}$ \\
\hline 2. & $\begin{array}{l}\text { Student had self-confidence when } \\
\text { sepeaking. }\end{array}$ & & $\sqrt{ }$ & $\begin{array}{l}\text { Student has self-confidence } \\
\text { when he is sepeaking. }\end{array}$ \\
\hline 3. & $\begin{array}{l}\text { Student was afraid of making } \\
\text { mistake when speaking. }\end{array}$ & $\sqrt{ }$ & & $\begin{array}{l}\text { Student is afraid of making } \\
\text { mistake when speaking } \\
\text { especially for her pronunciation } \\
\text { and grammar. }\end{array}$ \\
\hline 4. & $\begin{array}{l}\text { Student felt shy and looks like } \\
\text { nerveous when presenting the } \\
\text { material. }\end{array}$ & & $\sqrt{ }$ & $\begin{array}{l}\text { Student doesn't feel shy and } \\
\text { nerveous in her speaking }\end{array}$ \\
\hline 5. & $\begin{array}{l}\text { Student was lack of confidence } \\
\text { when speaking without preparation } \\
\text { at the first time. }\end{array}$ & & $\sqrt{ }$ & Student can overcome it. \\
\hline 6. & $\begin{array}{l}\text { Student was able to reduce his shy } \\
\text { and nervous feeling by trying to be } \\
\text { relax and keeping calm. }\end{array}$ & $\sqrt{ }$ & & $\begin{array}{l}\text { Student was able to reduce his } \\
\text { shy and nervous feeling by } \\
\text { trying to be relax and keeping } \\
\text { calm. }\end{array}$ \\
\hline
\end{tabular}

The Students' Speaking Anxiety: Psycho-Social Approach

Syahriana Pratiwi, Muhammad Zuhri Dj., \& Hasriati Nur, Page 16-27 
IJRETAL

International Journal of Research on English Teaching and Applied Linguistics, Vol. 1, No.1, June 2020

\begin{tabular}{|l|l|l|l|l|}
\hline 7. & $\begin{array}{l}\text { Social interaction like doing } \\
\text { conversation, expressed his idea } \\
\text { eventhough it was virtual class } \\
\text { could reduce the student's anxiety } \\
\text { in speaking. }\end{array}$ & $\sqrt{ }$ & & $\begin{array}{l}\text { Social interaction like doing } \\
\text { conversation and express his } \\
\text { idea could reduce the student's } \\
\text { anxiety in speaking. }\end{array}$ \\
\hline 8. & $\begin{array}{l}\text { Student had self-confidence and be } \\
\text { confortable when speaking by full } \\
\text { preparation such as mastering the } \\
\text { material, memorizing the text, } \\
\text { nothing the text wich wanted to be } \\
\text { presented and vocabulary } \\
\text { enrichment. }\end{array}$ & $\sqrt{ }$ & & $\begin{array}{l}\text { Student had self-confidence and } \\
\text { being confortable when speaking } \\
\text { by full preparation. }\end{array}$ \\
\hline 9. & $\begin{array}{l}\text { Controlling the student emotional } \\
\text { when speaking little by little could } \\
\text { reduce the student anxiety. }\end{array}$ & $\sqrt{ }$ & & $\begin{array}{l}\text { little by little could reduce the } \\
\text { student anxiety by Controlling } \\
\text { the student's emotional when } \\
\text { speaking }\end{array}$ \\
\hline 10. & $\begin{array}{l}\text { Giving motivation and attention to } \\
\text { students who were feeling shy, } \\
\text { nervous and anxious can reduce the } \\
\text { student anxiety. }\end{array}$ & $\sqrt{ }$ & $\begin{array}{l}\text { Motivation and attention were } \\
\text { needed by the student to reduce } \\
\text { her anxiety in speaking. }\end{array}$ \\
\hline
\end{tabular}

\section{Factors that Cause the Students Get Anxiety}

This part of the study focuses on what factors that cause the students get anxiety in speaking. Those factors as the object of the research have to be known by themselves directly. Exactly, it is needed something as the way that can give more information about that factors. Interviewing conducted in this research to collect the data. Therefore, this research used indepth interview that related to the open guided interview. The result of the interview found that factors are:

\section{a. Lack of preparation}

Based on the researcher's open guided interview answered by the students, some students answered that the factor of their anxiety because of unprepared material. It made them fear of making mistake. Here is the transcript;

Researcher: Do you feel anxious and afraid before beginning to speak in front of the class by using English? Can you explain the reason?

$R$ : Yes miss, I feel anxious and a little bit tense because it is not prepared and I don't have self-confidence".

This statement also is supported by other students.

$N A$ : Because of the short time to master in material and I usually memorize the text that I want to say. So, I sometimes feel afraid if I forget the text.

Based on the result of the interview above, it can be assumed that one of the students' factors in getting speaking anxiety is "the students were lack of preparation".

\section{b. Student's belief about language learning}

Learner belief means the situation when the students believe that they have to speak perfectly in a foreign language, in this condition, it's about the English material. The researcher found that students' beliefs about language learning become a factor of 
IJRETAL

International Journal of Research on English Teaching and Applied Linguistics, Vol. 1, No.1, June 2020

anxiety. They believe about language learning problems or the problems in material competence could break down into some materials such as grammar, vocabulary, pronounce, and some other English materials.

Based on the researcher's open guided interview answered by the students, there some students answering that they were less in English understanding. Here some of the answers of the students.

Researcher: Do you feel anxious and afraid before beginning to speak in front of the class by using English? Can you explain the reason?

AM: “yes miss, I don't understand about English. I still cannot speak English. feeling nervous cause I have not had many vocabulary to say and being afraid if my pronunciation is wrong".

This statement also is supported by other students.

NR : "Yeah, cause I'm less to know English miss and I am afraid if I speak by forgetting vocabulary.

Based on the result of the interview above, it can be assumed that one of the students' factors in getting speaking anxiety is "Student's belief about language learning”.

\section{c. Fear of making mistakes}

Being a fear of making mistakes was one of the factors that cause students to get anxiety in speaking. Based on the researcher's close guided interview answered by the students. They were afraid of making mistake because they will get a bad score and the other students will laugh. Here some of the answer of the students:

Researcher: Do you feel anxious and afraid before beginning to speak in front of the class by using English? Can you explain the reason?

PA : Yes miss, cause I feel afraid when I speak English and there are many mistakes. That is why I am anxious and shy to present the material by using English. When I was in elementary and junior high school I always made mistakes to perform by using English and my friends laughed at me. At the time I was so shy. Now, I still feel anxious when speaking English in front of the teacher and friends."

This statement also is supported by other students.

MS: "Yeah, because I feel fear of my pronunciation is not true".

Based on the result of the interview above, it can be assumed that one of the students' factors in getting speaking anxiety is "Student's belief about language learning".

In addition, the researcher also added finding from observation. In the observation, the students were anxious because they were afraid of making mistakes when arranging the sentence. The researcher found that some of the students looked afraid and uncertain to say the word, they took a long time and could not continue their speaking.

Based on the result of the interview above, it can be concluded that one of the students' factors in getting speaking anxiety is "Fear of making mistakes" and Personal and Interpersonal Anxieties",

Personal and interpersonal anxieties also became a factor that makes someone feel anxious. It was investigated in correlation with other social and psycho logical constructs. Based on the interview, personal and interpersonal anxieties often make anxious situations in language classrooms. This data supported by the result of an interview with the students, the situations made students felt nervous and uncomfortable when they spoke. 
IJRETAL

International Journal of Research on English Teaching and Applied Linguistics, Vol. 1, No.1, June 2020

Researcher: Do you feel anxious and afraid before beginning to speak in front of the class by using English? Can you explain the reason?

$R$ : "Every moments I will speak Englishi $n$ front of the class, i feel lack of confidence".

PA: "Maybe, It is caused since I had been laughed by my friends when speaking. My self-confidence and nerveousness are bring till now".

Based on the result of the interview above, it can be assumed that one of the students' factors in getting speaking anxiety is "Personal and Interpersonal Anxieties".

\section{B. DISCUSSION}

This section presents the discussion based on the findings of the research. The discussion is about and causes of anxiety in speaking for the eleventh grade of SMA Islam Athirah Bone and the way to reduce anxiety in speaking. The researcher requires the Findings as follows;

\section{Psycho-social approach reduced students' anxiety in speaking.}

Based on analyzing students' speaking anxiety by using a psycho-social approach, the students of SMA Islam Athirah Bone at the eleventh grade of Al-Hasib class got anxiety reduction in speaking.

In the form of self-awareness, students have developed a good awareness of the psychosocial approach because teachers have more opportunities to express their problems and concern related to feelings of anxiety when speaking.

In learning process, the students got encouragement and effort to learn English well. in addition, they also had a great willingness to participate in class activities especially speaking conversations, group presentations and others. Their fear of negative evaluations and low achievement has disappeared because the teacher told them to do activities in groups so that they are automatically able to increase their confidence to talk with their friends who have similar abilities to them.

They were also given time to prepare and present with friends before showing their speaking because they do it with groups. This group is able to create a situation that is very comfortable mentally rather than triggering anxiety.

\section{a). Social Interaction}

Social interaction is the most elementary unit of sociological analysis. The study of behavior per se is the proper subject matter of psychology, whereas sociology studies the organization of individuals, which can only begin with social interaction (Turner, 1988). In this case, the students interacted with her friends in the class such as doing conversation, sharing idea by grouping. Hence, the students told what they felt based on the situation. It could make them open minded and little by little could reduce their anxiety in speaking.

\section{b).Controlling the students' emotional}

Emotion help focus attention on the object of the emotion. Positive emotions relating to the activity, on the other hand, are assumed to focus attention on the activity, thus benefiting performance. Having emotions or feelings is normal, but controlling these emotions is part of what allows people to work each other. (Perkun, Frenzel, Goetz, \& Perry, 2007). Therefore, The students who were in bad situation such as anxious, nervous and shy in speaking, her emotions should be controlled by stay calm and stay positive. 
IJRETAL

International Journal of Research on English Teaching and Applied Linguistics, Vol. 1, No.1, June 2020

\section{c). Relaxation}

Relaxation is crucial to systematic desensitization (Lomont, 1967). The use of relaxation in treatment of medical conditions -is not new. In former days doctors prescribed "rest" which could be variously interpreted, but which basically included relaxation. The difference here is that "rest" involved passive use of relaxation, while modern approaches prefer a dynamic, self.. regulating approach to relaxation (Elton, G. D., \& Stanley, 1878)

By doing this, the students could more comfortable and reduce their anxiety.

\section{d.) Motivation}

Motivation is significant because even people with the required knowledge, skills, and abilities will perform poorly if they are not motivated to devote their time and effort to work (Veliu, Manxhari, \& Ujikani, 2015). It is suppoted by motivational theory by Maslow's Hierarchy Of Needs proposed that there are five different levels of needs people have to seek for satisfaction of their basic needs (Faizul, Haque, \& 1 Islam, 2014)

The first or lowest level is Physiological needs. Before these needs which include for example food, water, shelter and clothing are fulfilled a person doesn't have any other needs. When people don't feel hunger, thirst or cold, their needs are go to a second level. The second lowest level is Security needs. In that level a person needs to feel secure in his/her family and in a society, and feel protected against violence. The need for safety is manifested with job security, savings and for insurances of health,mental health, old age and disability.

Love and belonging needs is the third level of Maslow's hierarchy. After feeling secure, people need to feel that they receive and give love, they areappreciated and they have good friendships. The fourth level is Esteem needs. It is the need to be unique with self-respect and to enjoy esteem from other individuals. People want to evaluatethemselves highly and based on their achievement receive appreciation from other people. Lack of these needs may cause inferiority, helplessness and weakness. Highest level of Maslow's hierarchy of needs is need of Self-actualization. The development of this need is based on the satisfaction at the other four lower levels. It refers to the need of self-fulfillment and to the tendency to become actualized in what a person has potential.

One approach that also that used by teachers was a psycho-social approach where students were able to build their social relationships was doing social interaction by group activities. All things related to their thoughts, feelings, emotions, and attitudes were realized. It also supported the existence of social interactions that were often carried out able to make students more confident and no longer anxious. They got more guidance and motivation from the teacher such as relaxing, preparing the preparation before studying or perform and being positive thinking. (JACOBSON, 1938) attempted to place relaxation on a scientific basis and to make it a standard form of medical treatment" He has shown clinically and experimentally the usefulness.

Most of the students were incorporate the positive thinking of relaxation to reduce anxiety. On the other hand, the researcher also found that students used relaxation as a reduction of anxiety and healing the students cope with a stressful situation. Relaxation should be the keystone of all physiotherapeutic treatment (JONES, 1953) Taking a deep breath was strategy which used by mostly of students to make them relax and calm down in decreasing the feeling of anxiety during speaking performance. By using it, the students could keep control their emotional and feeling of frightened. As components of emotion, These appraisals are informed by our experiences, backgrounds, and cultures. Therefore, different people may have different emotional experiences even when faced with similar circumstances (Theory of motivation.Introduction to Psychology. , 2020). 
IJRETAL

International Journal of Research on English Teaching and Applied Linguistics, Vol. 1, No.1, June 2020

Based on the Erikson's theory of psycho-social development, adolescence 12 to 18 years or students are in important events especially social relationships. Teen needs to develop a sense of self and personal identity. Success leads to an ability to stay to yourself, while failure leads to role confusion and a weak sense of self (Z U. , 2020).

\section{The factors causes the students' anxiety in speaking English}

Based on the research finding of this thesis, the researcher found that most of the eleventh-grade students of SMA Islam Athirah Bone felt anxious when speaking. There was some cause speaking anxiety faced by students when practice speaking in class. The result of the interview showed that most of the students were anxious when speaking English in the class. The source was lack of preparation, learner belief about language learning, fear of making mistakes, and personal and Interpersonal anxiety.

The first factor that cause anxiety in speaking was lack of preparation before perform in speaking English. Preaparation means the action or process of making something ready for use or service or of getting ready for some occasion, test, or duty (Webster, 1828) Actually, preparation is very important before speaking English. The students prepare the material before practice to speak English in front of their friends and teacher, so the students could speak well without anxious.

The second factor that cause anxiety in speaking was learners' belief about language learning. In this factor contains much of factor come from the students self about English learning. Some of it: the worries about wrong in pronunciation, grammar, vocabulary, and any other factor in learning English that make them worried. The students

The third factor was fear of making mistakes. It was one of the factors contributing of students' anxieties in speaking. The students afraid of making mistake because the other students will laugh when they do something wrong and it make the students anxiety to speak in front of the class.

The fourth factor causing anxiety was personal and interpersonal factor. Personal and interpersonal factor here defined as a factor come from the inside of the student and factor with other people who influence to the personal of the student.

Based on the opend guided interview, a lot of students unconfident with themselves. Feeling nerveous when speaking in front of the class, nervous and shy.

Based on Shu Feng Tseng about factors cause students anxiety for ESL can arise from pressure by parents and teachers, lack of confidence and lack of preparation, fear of making mistakes, fear of foreigners and their behavior, and conditioning in childhood (Shu- Feng, 2012)

Three types of anxiety based on each sources, Trait anxiety, a more permanent disposition to be anxious (Scovel, 1978), is viewed as an aspect of personality. State anxiety is an apprehension experienced at a particular moment in time as a response to a definite situation (Spielberger, 1983), Finally, the last of the three types, situationspecific anxiety is related to apprehension unique to specific situation and events (Ellis, 1994)

Therefore, the researcher found 4 factors of students' anxiety in speaking at the eleventh grade of SMA Islam Athirah Bone arise from two findings above they are: lack of preparation, personal and interpersonal factor, learner beliefs about language learning and fear of making mistakes.

\section{CONCLUSION}

Based on the analyzing, it was found that the students' speaking anxiety could be reduced by using psycho-social approach. Through interview to the teacher and students and observation, those are: Social interaction, controlling the student's emotional, relaxation and motivation. Based on the test and interview and observation, the students felt anxious when speaking in front of their friends and teacher. The factors of speaking anxiety, those are: they are lack of preparation, 
IJRETAL

International Journal of Research on English Teaching and Applied Linguistics, Vol. 1, No.1, June 2020

learner's belief about language learning, fear of making mistake and personal interpersonal anxiety. The researcher suggestes for the English students, In learning speaking, the students are expected out to feel anxious when speaking English in the class or in front of their students and teacher. They also need to pay attention more about anxiety when spaking. For the English teachers, they should recognize that anxiety is one of the reason of why the students having difficulties in teaching and learning process especially when they should speak in front of public. Then teacher should acknowledge that the anxiety occurs. For the researcher,. suggested read some references as the comparison of this because requires a special attention to reduce the students' anxiety in speaking for the students' achievement

\section{REFERENCES}

Aydin, Selami (2008) An investigation on the language anxiety and fear of negative evaluation among Turkish EFL Learners. Asian EFL Journal.p. 423.

Benfatah Fatma Zohra, Implementing Cooperative Learning Technique in Teaching Speaking Skill (Algeria: University, 2012), p.7-8.

Blau, A. (1955). A unitary hypothesis of emotion: Anxiety, Emotions of Displeasure, and Affective Disorders, Psychoanalytic Quarterly, 24, 75-103.

Cora Lindsay, et al. "Learning and Teaching English A Course for Teacher". Oxford University Press, Vol. 11, No.3, 2006

Disorders, 443.

DAVISON, G. (1966): "Anxiety Under Total Curaris". Journal of Nervous \& Mental

Elaine K. Horwitz, Michael B. Horwitz, Joann CopeReviewed. Foreign Language Classroom Anxiety (Blackwell:2012), P.125. Press, 1994.

Ellis, R. (1994). The study of second language acquisition. Oxford: Oxford University

Faizul, Mohammad Haque; Haque, Mohammad Aminul; 1 Islam, Md. Shamimul. Motivational Theories - A Critical Analysis. ResearchGate. 2014.p. 62

Gokhan Ozturk and Nurdan Gurbuz. Speaking Anxiety Among Turkish EFL Learners: The case at a state university ( Turkey: JLLS, 2014), p.1.

Hakan Karatasa, Bulent Alci, Mehtap Bademcioglu, Atilla Ergin. An Investigation into University Students' Foreign Language Speaking Anxiety (Turkey: Elseiver, 2016), p. 383.

Hendra Heriansyah. Speaking Problem Faced By The English Department Students Of Syiah Kuala University ( Aceh: Syiah Kuala University, 2012), P.38.

https://www.merriam-webster.com/dictionary/preparation. (september,2020)

Jack C. Richards, dkk., Methodology in Language Teaching An Anthology of Current Practice (Cambridge University press, 2002), p. 204 Chicago.

JACOBSON, E.. (1938): Progressive Muscle Relaxation. University of Chicago Press,

JONES, H. M. (1953): "A Review of Relaxation". Physical Therapy, 34 : $570 \sim$

K Punch, introduction to Research Methods in Education, Sage Publication, Los Angeles, 2009

The Students' Speaking Anxiety: Psycho-Social Approach

Syahriana Pratiwi, Muhammad Zuhri Dj., \& Hasriati Nur, Page 16-27 
IJRETAL

International Journal of Research on English Teaching and Applied Linguistics, Vol. 1, No.1, June 2020

Liliana Marcela UsmaTrejos, et al.Teaching Speaking And Speaking Skill Assessment In A 10th Grade Of A Public High School From Pereira (Pereira: Universidad Tecnológica De Pereira Facultad De BellasArtes Y HumanidadesLicenciatura En LenguaInglesa, 2013), p. 20.

Hall.

Mullins, L. (2007) Management and Organizational Behaviour. 8th ed. FT/Prentice

Muzafer Sherif. Social Interaction (New york: Routladge, 2017), P.4.

RACHMAN, S. (1965): "Studies in Desensitization, the Separate Effect of Relaxation and D.esensiti zation". Behaviour Research and Therapy, $3: 245$

Saiful Anwar. Maggie's Psychosocial Crises Revealed In Stephen Crane's. Maggie: A Girl Of The Street(Psychosocial Approach).(The State Islamic University Maulana Malik Ibrahim Malang. Malang:2014) p.12

Saiful Anwar. Maggie's Psychosocial Crises Revealed In Stephen Crane's. Maggie: A Girl Of The Street(Psychosocial Approach).(The State Islamic University Maulana Malik Ibrahim Malang. Malang:2014) p.13-16

Scovel, T. (1978). The effect of affect on foreign language learning: A review of the anxiety research. Language Learning, 28, 129-42.

Shu- Feng Tseng. The Factors cause Language Anxiety for ESL/EFL Learners in Learning Speaking. (Department of Aplied Foreign Language: Cheng Shiu University, 2012), P.38.

Shu- Feng Tseng. The Factors cause Language Anxiety for ESL/EFL Learners in Learning Speaking. (Department of Aplied Foreign Language: Cheng Shiu University, 2012), P.38.

Shu- Feng Tseng. The Factors cause Language Anxiety for ESL/EFL Learners in Learning Speaking. (Department of Aplied Foreign Language: Cheng Shiu University,(2012),P.38

Spielberger, C. (1983). Manuel for the state-trait anxiety inventory. Palo Alto, Calif.: Consulting Psychologists Press.

V. Coulshed. The Psychosocial Approach: Sosial Work Practice.(BRITISH Association of social workers:1998)

WOLPE, J. (1958): Psychotherapy by Reciprocal Inhibition. Stanford University Press.

Zulinnuha (24, June 2020) Eriksons' Theory of Pycho-social Development. Dilib,uinsby.ac.id 